\title{
EFFECTS OF VITAMIN E SUPPLEMENTATION ON SOME ASPECTS OF HEMATOLOGICAL VARIABLES IN PATIENTS OF HEMOLYTIC ANEMIA WITH GLUCOSE 6 PHOSPHATE DEHYDROGENASE (G6PD) DEFICIENCY
}

\author{
NAYMA SULTANA ${ }^{1}$, NOORZAHAN BEGUM ${ }^{2}$, SHELINA BEGUM ${ }^{3}$, SULTANA FERDOUSI $^{4}$, TASKINAALI ${ }^{5}$
}

Lecturer,. Department of Physiology, Dhaka Dental College, Dhaka', Professor \& Chairman ${ }^{2}$, Associate Professor ${ }^{3}$, Assistant Professor ${ }^{4}$, Assistant Professor ${ }^{5}$, Department of Physiology, Bangabandhu Sheikh Mujib Medical University (BSMMU), Dhaka

\begin{abstract}
:
Vitamin $E$ works within the cell membrane as a biological antioxidant and may prevent premature destruction of RBC in Glucose 6-phosphate dehydrogenase (G6PD) deficient hemolytic anemia. Changes in some of the hematological variables like hemoglobin $(\mathrm{Hb})$ concentration, total count (TC) of RBC, packed cell volume (PCV) and reticulocyte counts may occur due to hemolysis of RBC in G6PD deficiency. In the present study the role of vitamin $E$ supplementation on these changes were observed in reducing chronic hemolysis in anemic patients with glucose 6-phosphate dehydrogenase (G6PD) deficiency. For this, a total number of 102 subjects with age ranged from 5 to 40 years of both sexes were included in the study. Among them 68 were G6PD enzyme deficient patients, of whom 34 were in supplemented group (experimental group) and 34 were nonsupplemented group (control group). The supplemented group received vitamin $E$ supplementation for 60 consecutive days at a dose of $800 \mathrm{IU} /$ day for adult and $400 \mathrm{IU} /$ day for children $\leq 12$ years (in a divided dose i,e. 4 times daily). Age and sex matched 34 apparently healthy subjects with normal blood G6PD level were taken to observe the baseline data (healthy control) and also for comparison. All the G6PD deficient patients were selected from Out Patient Department (OPD) of hematology. Bangabandhu Sheikh Mujib Medical University (BSMMU). Dhaka, Bangladesh during the period of July 2005 to June 2006 and all the healthy subjects were selected from personal contact. Blood G6PD level, $\mathrm{Hb} \%$. TC of RBC, PCV, reticulocyte count and serum bilirubin level of all subjects were measured by standard laboratory techniques. All the parameters were measured on day 1(one) of their $1^{\text {st }}$ visit forall the groups and also were on day 60 in deficient group. Data were compared among the different groups, also in supplemented group just before and after supplementation. Analysis of data was done by appropriate statistical method. Mean blood Hb\%, TC of RBC and PCV were significantly lower but reticulocyte count and serum bilirubin levels were significantly higher in patients suffering from hemolytic anemia due to G6PD deficiency in comparison to those of the healthy control. After supplementation with vitamin $E$ (i,e. on day-60) Hb concentration, total count of $R B C, P C V$ were significantly increased whereas, reticulocyte count and serum bilirubin levels were significantly decreased towards those of healthy control in supplemented group of patients in comparison to those of their pre-supplemented (day-1) and non-supplemented groups both on day-1 and day-60. Therefore, from this study it may be concluded that, deterioration of some of the hematological parameters occur in G6PD deficient hemolytic anemic patients, improvement of which occur following vitamin E supplementation, which clearly indicates the role of this antioxidant vitamin in reducing the rate of hemolysis in this group of patients. So, vitamin $E$ supplementation can be considered along with other drugs to treat this group of patients.
\end{abstract}

(Bangladesh J Physiol Pharmacol 2006; 22(1/2) : 12-17)

\section{INTRODUCTION}

G6PDdeficiency is an x-linked disorder, which leads to hemolysis of red blood cells under oxidative stress ${ }^{1}$. More than 400 million of world populations are affected by this enzymopathy ${ }^{2}$. The prevalence of G6PD enzyme

Address of correspondence : Nayma Sultana, Dhaka Dental College, Mirpur-14, Dhaka-1216. Tel: 01711269352, E-mail: nayma_sultana@yahoo.com deficiency is high in Africa, the Mediterranean region, the Middle East, the South-East Asia and also may be the population of Indian subcontinent ${ }^{3}$. Besides anemia, other common complications of G6PD deficiency are neonatal jaundice and sporadic hemolytic crisis caused by some drugs, infections or ingestion of fava beans ${ }^{4}$. In addition, hemolytic episodes in G6PD deficiency may also occur as a complication of bacterial infection 
(pneumonia), upper respiratory tract infection and also of both acute and chronic viral hepatitis $5,6,7,8$. Massive intravascular hemolysis due to G6PD deficiency may lead to renal failure. ${ }^{9,7}$.

Glucose 6 phosphate dehydrogenase (G6PD) catalyses the first step of hexose monophosphate shunt. Its deficiency is one of the common enzyme defects affecting erythrocyte metabolism. G6PD deficient erythrocytes can not maintain sufficient levels of NADPH and reduced glutathione which are required to protect RBC from oxidative stress ${ }^{10}$.

A significant decrease in hemoglobin concentration total count of RBC and hematocrit value with a marked increase in reticulocyte count are the associated findings in G6PD enzyme deficient hemolytic anemia $8,11,12,13,14$. In addition, hyperbilirubinemia may also occur in this group of enzyme deficient patients. In most of the cases this hyperbilirubinemia results from excessive destruction of $\mathrm{RBC}^{15}$.

Vitamin $E$ is one of the major lipid soluble antioxidant. It prevents oxidation of polyunsaturated fatty acids and thus protects red blood cells from oxidative stress-induced lyses ${ }^{11}$. Again, deficiency of vitamin $E$ is a common feature in genetic anemia, including G6PD deficiency hemolytic anemia due to its increase consumption 16,17 . Supplementation of vitamin $E$ may have an important role in maintaining red cell membrane integrity by reducing osmotic fragility of erythrocyte ${ }^{18}$ and can minimize the severity of hemolysis in G6PD deficient patients ${ }^{8}$. Again, vitamin $E$ supplementation can restore the required amount of vitamin $E$ level in this group of patients, and thus may prevent hemolysis by improving red blood cells survival. As a consequences, there are sustained improvement in hemoglobin concentration, hematocrit value, reticulocyte count $11,12,13$.

In Bangladesh there is lack of adequate information about deficiency of G6PD enzyme among the anemic patients. Only one study regarding the hematological parameters of G6PD enzyme deficient patients has ben reported in our country ${ }^{19}$. But no published data regarding effects of vitamin E supplementation in these G6PD enzyme deficient patients are available. For this, the present study was aimed at to observe some aspects of hematological parameters in G6PD deficient hemolytic anemic patients both before and after supplementation of vitamin $E$, in order to explore its role in preventing red cell lyses and thereby maintains the normal hematological status in these enzyme deficient patients. The output of the study may be helpful to create awareness about the deficiency of G6PD enzyme in anemic patients as well as the role of vitamin $E$ in minimizing the risk of complications. Moreover it can provide information to clinicians for better management of these patients.

\section{METHODS}

The present Prospective interventional study was carried out in the Department of Physiology, BSMMU, Dhaka from July 2005 to June 2006. In this study, a total number of 102 subjects with age ranged from 5 to 40 years of both sexes were included. Among them 68 were patients of hemolytic anemia with blood G6PD level below the normal reference range ${ }^{20}$, of whom 34 were in supplemented group (study group) and 34 were without supplementation and was considered as nonsupplemented group (control group). The supplemented group received vitamin $E$ supplementation for 60 consecutive days at a dose of $800 \mathrm{IU} /$ day for adult and $400 \mathrm{IU} /$ day for children $\leq 12$ years; in a divided dose i,e. 4 times daily ${ }^{10,11}$. Age and sex matched 34 apparently healthy subjects with normal blood G6PD level were taken to observe the baseline data (healthy control) and also for comparison. All the G6PD deficient patients were selected from Out Patient Department (OPD) of Hematology, Bangabandhu Sheikh Mujib Medical University (BSMMU), Dhaka, and all the healthy subjects were selected from personal contact. Blood G6PD level, $\mathrm{Hb} \%$, TC of $\mathrm{RBC}$, reticulocyte count and serum bilirubin level was done in all the subjects on day 1 (one) of their $1^{\text {st }}$ visit and in G6PD enzyme deficient groups of subjects also on day-60. Data were compared among healthy control, supplemented, non-supplemented and also within supplemented groups just before and after supplementation. All the subjects belonged to middle and lower middle socio-economic status. Patients with acute hemolytic episode or received blood transfusion in the last two months and $b$ thalassemia trait were excluded from the study. The objectives and benefits of the study were explained to all the subjects to ensure their voluntary participation and a written informed consent was taken from each subject prior to the study.

Four (4) $\mathrm{ml}$ of venous blood was drawn from antecubital vein under aseptic precautions. Then $2 \mathrm{ml}$ of blood was taken in an EDTA test tube for determination of erythrocyte G6PD level and the hematological parameters. The remainder was transferred in a testtube where serum was separated for estimation of bilirubin level.

Erythrocyte G6PD enzyme level was determined by spectrophotometric method 21 and the hematological parameters were estimated by standard laboratory technique $22-24$. Serum bilirubin was determined by Jendrassik /Grof method ${ }^{25}$. All of these tests were done in the Department of Physiology, BSMMU, Dhaka. Data were expressed as Mean \pm SD. One-way ANOVA (PostHoc Test), independent-samples(unpaired) ' $t$ ' test and paired-samples ' $t$ ' test were done as the tests of significance wherever applicable. The statistical analysis was done by using SPSS programme version 12. $p$ value $<0.05$ was considered as significant. 


\section{RESULTS:}

Mean erythrocyte G6PD levels were significantly $(p<0.001)$ lower in G6PD enzyme deficient group of patients when compared to that of healthy control (tableI). The mean $\mathrm{Hb} \%$, TC of RBC and PCV were significantly $(p<0.001)$ lower in both the G6PD deficient groups in comparison to those of healthy control group on day-1. After supplementation of vitamin $\mathrm{E}$ (i,e. on day-60) $\mathrm{Hb} \%$, TC of RBC and PCV were significantly $(p<0.001)$ increased in comparison to those of their presupplemented (day-1) and also of non-supplemented groups both on day- 1 and day-60 and returned almost toward the values of healthy control (table-l1).

Patients with G6PD deficiency had significantly $(p<0.001)$ higher reticulocyte count and serum bilirubin level compared to those of healthy control. These values were decreased significantly $(p<0.001)$ toward the values of healthy control in G6PD deficient group following vitamin E supplementation. (table-III).

Table-I

Mean $( \pm S D$ ) Erythrocyte G6PD level in different study groups $(n=102)$

\begin{tabular}{lccc}
\hline Groups & $\mathrm{n}$ & $\mathrm{U} / 10^{12} \mathrm{RBC}$ & $\mathrm{U} / \mathrm{g} \mathrm{Hb}$ \\
\hline $\mathrm{A}$ & 34 & $191 \pm 18.8$ & $6.69 \pm 1.19$ \\
& & $(161-226)$ & $(5.00-9.60)$ \\
$\mathrm{B}_{1}$ & 34 & $105 \pm 9.38$ & $3.29 \pm 0.34$ \\
& & $(90-121)$ & $(2.38-3.90)$ \\
$\mathrm{C}_{1}$ & 34 & $105 \pm 10.09$ & $3.31 \pm 0.33$ \\
& & $(85-122)$ & $(2.60-3.84)$
\end{tabular}

\section{Statistical analysis:}

\begin{tabular}{lllll}
\hline Groups & & \multicolumn{2}{c}{$p$ value } \\
\hline A & vs & $B_{1}$ & $0.000^{* * *}$ & $0.000^{* * *}$ \\
A & vs & $C_{1}$ & $0.000^{* * *}$ & $0.000^{* * *}$ \\
$B_{1}$ & vs & $C_{1}$ & $0.747^{n s}$ & $0.893^{\text {ns }}$ \\
\hline
\end{tabular}

Group $\mathbf{A}=$ Healthy subjects for baseline and control.

Group B = Hemolytic anemic patients with G6PD deficiency (nonsupplemented group).

Group C = Hemolytic anemic patients with G6PD deficiency (supplemented group).

$$
\mathrm{B}_{1} \text { and } \mathrm{C}_{1}=\text { On day } 1
$$

Figures in parentheses indicate ranges.

$\star \star \star=$ Significant at $p<0.001$.

ns $=$ Not significant

$\mathrm{n}=$ Number of subjects.
Table-II

Mean $( \pm S D) H b$ concentration, TC of RBC and PCV in different study groups $(n=102)$.

\begin{tabular}{lcccr}
\hline Groups & $n$ & $\mathrm{Hb}$ & $\mathrm{RBC}$ & \multicolumn{1}{c}{$\mathrm{PCV}$} \\
& & $(\mathrm{g} / \mathrm{dl})$ & $\left(\right.$ cell number $\left.\times 10^{12} / \mathrm{L}\right)$ & \multicolumn{1}{c}{$(\%)$} \\
\hline $\mathrm{A}$ & 34 & $14.26 \pm 1.44$ & $4.66 \pm 0.53$ & $42 \pm 2.41$ \\
& & $(12-18)$ & $(4-6.1)$ & $(38-46)$ \\
$\mathrm{B}_{1}$ & 34 & $10.15 \pm 0.94$ & $3.72 \pm 0.19$ & $31.5 \pm 3.63$ \\
& & $(8.5-11.5)$ & $(3.4-4)$ & $(25.5-37.26)$ \\
$\mathrm{B}_{2}$ & 34 & $10.15 \pm 0.86$ & $3.74 \pm 0.17$ & $31.88 \pm 3.51$ \\
& & $(8.5-11.50)$ & $(3.5-4.0)$ & $(26-38)$ \\
$\mathrm{C}_{1}$ & 34 & $10.34 \pm 1.00$ & $3.75 \pm 0.23$ & $32 \pm 3.73$ \\
& & $(8.5-12.5)$ & $(3.4-4.2)$ & $(25.5-37.5)$ \\
$\mathrm{C}_{2}$ & 34 & $13.06 \pm 0.83$ & $4.31 \pm 0.19$ & $39 \pm 2.24$ \\
& & $(11.5-14.5)$ & $(4-4.8)$ & $(34.5-42.6)$
\end{tabular}

Statistical analysis:

\begin{tabular}{llllll}
\hline \multicolumn{1}{l}{ Groups } & \multicolumn{4}{l}{ p value } \\
\hline A & vs & $\mathrm{B}_{1}$ & $0.000^{* * *}$ & $0.000^{* * *}$ & $0.000^{* * *}$ \\
$\mathrm{~A}$ & vs & $\mathrm{C}_{1}$ & $0.000^{* * *}$ & $0.000^{* * *}$ & $0.000^{* * *}$ \\
$\mathrm{~A}$ & vs & $\mathrm{B}_{2}$ & $0.000^{* * *}$ & $0.000^{* * *}$ & $0.000^{* * *}$ \\
$\mathrm{~A}$ & vs & $\mathrm{C}_{2}$ & $0.000^{* * *}$ & $0.002^{* *}$ & $0.000^{* * *}$ \\
$\mathrm{~B}_{1}$ & vs & $\mathrm{C}_{1}$ & $0.413^{\mathrm{ns}}$ & $0.495^{\mathrm{ns}}$ & $0.588^{\mathrm{ns}}$ \\
$\mathrm{B}_{2}$ & vs & $\mathrm{C}_{2}$ & $0.000^{* * *}$ & $0.000^{* * *}$ & $0.000^{* * *}$ \\
$\mathrm{~B}_{1}$ & vs & $\mathrm{B}_{2}$ & $0.946^{\mathrm{ns}}$ & $0.350^{\mathrm{ns}}$ & $0.082^{\mathrm{ns}}$ \\
$\mathrm{C}_{1}$ & vs & $\mathrm{C}_{2}$ & $0.000^{* * *}$ & $0.000^{* * *}$ & $0.000^{* *}$ \\
\hline
\end{tabular}

Group $\mathbf{A}=$ Healthy subjects for baseline and control.

Group B = Hemolytic anemic patients with G6PD deficiency (nonsupplemented group)

Group C = Hemolytic anemic patients with G6PD deficiency (supplemented group).

$$
\begin{aligned}
& B_{1} \text { and } C_{1}=\text { On day } 1 . \\
& B_{2} \text { and } C_{2}=\text { On day } 60
\end{aligned}
$$

Figures in parentheses indicate ranges

${ }^{\star \star \star}=$ Significant at $p<0.001$.

** = Significant at $p<0.01$.

ns $=$ Not significant

$\mathrm{n}=$ Number of subjects. 
Table-III

Mean $( \pm S D$ ) Reticulocyte counts in different study groups $(n=102)$

\begin{tabular}{|c|c|c|c|c|}
\hline \multicolumn{2}{|c|}{ Groups } & $n$ & Reticulocyte (\%) & Bilirubin (mg/dl) \\
\hline A & \multicolumn{2}{|c|}{34} & $\begin{array}{c}1.31 \pm 0.48 \\
(0.5-2)\end{array}$ & $\begin{array}{c}0.6 \pm 0.16 \\
(0.3-1)\end{array}$ \\
\hline $\mathrm{B}_{1}$ & \multicolumn{2}{|c|}{34} & $\begin{array}{c}3.06 \pm 0.44 \\
(2.4-4)\end{array}$ & $\begin{array}{l}1.78 \pm 0.43 \\
(1.25-3.5)\end{array}$ \\
\hline $\mathrm{B}_{2}$ & \multicolumn{2}{|c|}{34} & $\begin{array}{c}3.09 \pm 0.44 \\
(2-4)\end{array}$ & $\begin{array}{c}1.79 \pm 0.42 \\
(1-3.5)\end{array}$ \\
\hline$C_{1}$ & \multicolumn{2}{|c|}{34} & $\begin{array}{c}2.79 \pm 0.55 \\
(2-4)\end{array}$ & $\begin{array}{l}1.51 \pm 0.66 \\
(0.26-3.5)\end{array}$ \\
\hline$C_{2}$ & \multicolumn{2}{|c|}{34} & $\begin{array}{c}1.43 \pm 0.48 \\
(0.5-2.2)\end{array}$ & $\begin{array}{c}0.82 \pm 0.29 \\
(0.4-1.5)\end{array}$ \\
\hline \multicolumn{5}{|c|}{ Statistical analysis: } \\
\hline \multicolumn{3}{|c|}{ Groups } & \multicolumn{2}{|c|}{$p$ value } \\
\hline$A$ & vs & $\mathrm{B}_{1}$ & $0.000^{* * *}$ & $0.000^{* * *}$ \\
\hline$A$ & vs & $C_{1}$ & $0.000^{* *}$ & $0.000^{* *}$ \\
\hline A & vs & $\mathrm{B}_{2}$ & $0.000^{* * *}$ & $0.000^{* *}$ \\
\hline$A$ & vs & $\mathrm{C}_{2}$ & $0.607^{n s}$ & $0.001^{\star *}$ \\
\hline $\mathrm{B}_{1}$ & vs & $C_{1}$ & $0.027^{*}$ & $0.052 \mathrm{~ns}$ \\
\hline$B_{2}$ & vs & $\mathrm{C}_{2}$ & $0.000^{* \star *}$ & $0.000^{* * *}$ \\
\hline$B_{1}$ & vs & $\mathrm{B}_{2}$ & $0.659 \mathrm{~ns}$ & $0.817^{\mathrm{ns}}$ \\
\hline $\mathrm{C}_{1}$ & vs & $\mathrm{C}_{2}$ & $0.000^{* * *}$ & $0.000^{* * *}$ \\
\hline
\end{tabular}

Group $A=$ Healthy subjects for baseline and control.

Group $\mathbf{B}=$ Hemolytic anemic patients with G6PD deficiency (nonsupplemented group).

Group C = Hemolytic anemic patients with G6PD deficiency (supplemented group).

$\mathrm{B}_{1}$ and $\mathrm{C}_{1}=$ On day 1

$\mathrm{B}_{2}$ and $\mathrm{C}_{2}=$ On day 60

Figures in parentheses indicate ranges.

${ }^{* \star *}=$ Significant at $p<0.001$.

${ }^{\star}=$ Significant at

$\mathrm{p}<0.05$. ns $=$ Not significant.

$\mathrm{n}=$ Number of subjects.

\section{DISCUSSION:}

In the present study, before supplementation of vitamin $E$, all the observed hematological parameters were significantly lower along with significantly higher reticulocyte count and serum bilirubin level in G6PD deficient patients when compared to those of healthy control. These observations are in agreement with those of some other workers of different countries $11,12,14,15$. On the contrary, a normal red cell count with a normal hematocrit value were also observed by some other groups of researchers in G6PD deficient hemolytic anemic patients. Again, no significantly higher values of reticulocyte count and serum bilirubin level were found in a similar group of patients 26,27 .

Again, in this study after vitamin $\mathrm{E}$ supplementation $\mathrm{Hb} \%, \mathrm{TC}$ of RBC and PCV were significantly increased, whereas, reticulocyte count and serum bilirubin were significantly decreased in this group of patients. These observations are in consistent with those of some investigators of different countries ${ }^{11,12,13,14,28}$. On the other hand, no remarkable changes in some of the hematological parameters like reticulocyte count and hematocrit value was observed by some other researchers ${ }^{29}$. They also stated that, this might be due to short duration and low dose of vitamin $E$ supplementation in their study.

Abnormal degradation of $\mathrm{Hb}$, disturbances of intracellular metabolism and changes in the RBC membrane integrity might be the possible underlying factors responsible for early destruction of erythrocytes in G6PD deficient hemolytic anemia. In addition, lower level of reduced glutathione in G6PD deficient red blood cells with their limited ability to resists oxidative stress, could lead to their premature destruction ${ }^{10}$. Therefore, decreased level of $\mathrm{Hb}$, TC of RBC, PCV may be the usual feature in hemolytic anemia with G6PD deficiency as a consequence of excessive hemolysis and these are more marked in oxidative stress 14,30. Reticulocyosis and hyperbilirubinemia in G6PD deficiency may be caused by shorter red cell life span and subsequent increased rate of erythropoiesis and increased rate of hemilysis ${ }^{12,14}$. The normal red cell count with normal hematocrit value in some other study may be due to increased rate of erythropoiesis to compensate excessive hemolysis in this enzyme deficient patients. Again, a normal reticulocyte count with a normal serum bilirubin level in another study might be due to minor sub-clinical hemolysis of those enzyme deficient patients.

The comparative analysis of some hematological parameters in G6PD deficient patients and healthy control indicates occurrence of significant anemia in the present series of patients. Defect in membrane integrity, is the most likely cause of excess hemolysis as indicated by the significant lower values of all the hematological parameters in G6PD deficient hemolytic anemia. As G6PD is essential for the maintenance of integrity of red cell membrane, therefore deficiency of this enzyme causes more hemolysis which is further supported by increased reticulocyte count and serum bilirubin level in these patients. 
Vitamin $E$ might be the most effective natural, lipid soluble, chain breaking antioxidant, which scavenges free radicals, thus prevent free radical- induced lipid peroxidation in the RBC membrane thereby causing decreased hemolysis and increased RBC survival ${ }^{13,31}$. However, improvement of all these hematological parameters as well as the serum bilirubin towards the normal level by 60 days supplementation of vitamin $E$ in the patients of present series is suggestive of these evidences.

Therefore, this study concludes a higher rate of hemolysis in hemolytic anemic patients with G6PD deficiency and vitamin $E$ supplementation improves some aspects of hematological status towards normal and thus causes decrease of hemolysis to some extent. Determination of serum vitamin E level, red cell half-life and long time supplementation of vitamin $E$ with larger sample size may be helpful to explore the possibility that long term vitamin $\mathrm{E}$ supplementation might reduce the severity of acute hemolytic crisis. However, from this type of study it is difficult to comment on the exact mechanism of vitamin $E$ involved in improving hematological status by reducing hemolysis of RBC in G6PD deficient hemolytic anemic.patient.

\section{REFERENCES:}

1. Craig JIO, Celland DM, Ludlam CA. Blood disorders. In: A.B. Nicholas, R.C. Nicki, R.E. Brain and J.A.A. Hunter, (eds). Davidson's Principles \& Practice of Medicine, New York: Churchil Livingstone Elsevier, 2006; pp. 9901064.

2. Luzzato L, Mehta A, Meloni T. Hemoglobin and Haptoglobin in G6PD deficiency . Br. J. Haematol 1995; $91: 511-12$

3. Smith ECG. Disorders of red cell metabolism. In: A.V. Hoffbrand, D. Oatovsky, and E.G.D. Tuddenham. Postgraduate hematology, Oxford: Blackwell publishing Ltd. 2005

4. Champe PC, Haney RA, Ferrier DR. Lippincott's Illustrated Reviews. New Delhi: JP Brothers Medical Publishers (P) LTD. 2005

5. Burka RE, Weaver Z, Marks AP. Clinical spectrum of hemolytic anemia associated with glucose-6-phosphate dehydrogenase deficiency. Ann Intern Med, 1966; 64: 817-25.

6. Salen G, Goldstein F, Hauran F, Wirts WC. Acute hepatitis in patients with glucose-6-phosphate dehydrogenase deficiency. Ann Intern Med 1966; 65: 1210-20.

7. Wanachiwanawin W, Piankijagum A. Severe hyper bilirubinemia in glucose-6-phosphate dehydrogenase deficient patients during viral hepatitis. J Med Assoc Thai1990; 73(10): 552-55.
8. Gostman I, Muszkat M. Glucose-6-phosphate dehydrogenase deficiency is associated with increased initial clinical severity of acute viral hepatitis. J Gastroenterol hepatol 2001; 16(1): 1239-43.

9. Phillips SM, Silvers NP. Glucose-6-phosphate dehydrogenase deficiency, infectious hepatitis, acute hemolysis and renal failure. Ann Intern Med, 1969; 70(1): pp. 99-104.

10. Beutler E. Glucose-6-phosphate dehydrogenase deficiency. Blood.1994; 84: 3613-36.

11. Corash L, Spielberg S, Bartsocas C, Boxer L, Steinherz R, Sheetz M, Schlessleman J, Schulman JD. Reduced chronic hemolysis during high-dose vitamin $E$ administration in Mediterranean-type glucose-6-phospate dehydrogenase deficiency. N Eng J Med, 1980; 303: pp. 416-20.

12. Hafez $M$, Amar $E S$, Zedan $M$, Hammad $H$. Sorour $A H$, Desouky SA, Gami N. Improved erythrocyte survival with combined vitamin $E$ and selenium therapy in children with glucose-6-phosphate dehydrogenase deficiency and mild chronic hemolysis. J Pediatr, 1986; 108: pp. 558-61.

13. Usberti M, Gerardi GM, Micheli AM, Piola T, Bufano G, Gaggia P, Movilli E, Cancarini GC, Miarinis SD, D'Avolio G, Broccoli R, Manganoni A, Albertini A, Lorenzo DD. Effects of a vitamin E-bonded membrane and of glutathione on anemia and erythropoietin requirements in hemodyalysis patients. J Nephrol, 2002; 15: pp. 558-64

14. Sarikcioglu SB, Oner G, Tercan E. Antioxidant effect of Egb 761 on hydrogen peroxide-induced lipoperoxidation of G6PD deficient erythrocytes. Phytother Res, 2004; 18(10), pp. 837-40.

15. Weng $\mathrm{YH}, \mathrm{Chou} \mathrm{YH}$, Lien RI. Hyperbilirubinemia in healthy neonats with glucose-6-phosphate dehydrogenase deficiency. Early Hum Dev, 2003; 71 (2): pp. 139-36.

16. Chan AC, Chow CK, Chiu D. Interaction of antioxidant and their implication in genetic anemia. Proc Soc Exp BiolMed, 1999; 222(3): pp. 274-82.

17. Hasanato RMW. Zinc, antioxidant vitamin deficiency in patients with severe sickle cell anemia. Ann. Saudi Med, 2006; 26 (1): pp: 17-21.

18. Jaja SI, Aigbe PE, Gbenebipse S, Temiyp, EO. Changes in erythrocytes following supplementation with alphatocopherol in children suffereing from sickle cell anemia. Niger Postgrad Med J, 2005; 12(2), pp. 110-14.

19. Razzak M. Study on some aspects of hematological indices in G6PD enzyme deficient and non-deficient hemolytic anemia. M.Phil. thesis, BSMMU, Dhaka 2003.

20. Milne DB. Trace elements. In: C.A. Burtis and E.R. Ashwood, (eds). Tietz text book of clinical chemistry, Philadelphia: WB Saunders company. 2001. pp. 568-83.

21. Lab Care Diagnostics (India) Pvt. Ltd. Accucare Glucose6-phosphate dehydrogenase Quant, Mumbai 2005.

22. Van Kampen EJ, Zijlstra WG. Clin Chem Acta, 1961; 6: pp 538. 
23. Russia $U$, Soad SK. Routine hematological tests. In: Mukherjee KL, (ed). Medical Laboratory technology, New Delhi: McGraw-Hill. 1988. pp. 242-44.

24. Dacie SJV, Lewis SM. Practical Hematology. London: ELBS. 1994.

25. Jendrassik L, Grof P, Biochem Z, 1938; 81: pp. 297.

26. Ishay DB, Izak G. Chronic hemolysis associated with glucose-6-phosphate dehydrogenase deficiency. J lab Clin Med, 1964; 63(6): pp. 1002-08.

27. Mengel AC, Metz E, Yancy SW. Anemia during acute infections. Arch Int Med, 1967; 119: pp. 287-90.

28. Dissayabutra $T$, Tosukhaowong $P$, Sesa $P$. The benefits of vitamin $C$ and Vitamin $E$ in children with beta-thalassemia with high oxidative stress. J Med Assoc Thai, suppl 4; 2005; pp. 317-21.
29. Newman JG, Newman TB, Bowie LJ, Mendelson J. An examination of the role of vitamin $E$ in glucose-6-phosphate dehydrogenase deficiency. Clin Biochem, 1979; 12(5): pp.149-51.

30. Eldamhougy S, Elhelw Z, Yamamah G, Hussein L, Fayyad 1, Fawzy D. The vitamin E status among glucose-6phosphate dehydrogenase deficient patients and effectiveness of_oral vitamin E. Int J Vitam Nutr Res, 1988; 58(2): pp. 184-88.

31. Gumustekin K, Chiftci M, Coban A, Altikat S, Aktas O, Gul $M$, Timur $H$, Dane $S$. Effects of nicotine and vitamin $E$ on glucose-6-phosphate dehydrogenase activities in some rat tissues in vivo and in vitro. $J$ Enzyme Inhib Med Chem, 2005; 20(5): pp. 497-502. 